\title{
PERSEPSI PESANGGEM TERHADAP ASPEK EKONOMI DAN EKOLOGI HUTAN di KABUPATEN BLITAR
}

\author{
Eko Wahyu Budiman \\ Mahasiswa Magister Agribisnis Universitas Muhammadiyah Malang \\ email: ekowahyu.wahyu@gmail.com
}

\begin{abstract}
Forests are natural resources that provide benefits to human welfare, both directly (intangible) and indirectly (tangible). The existence of forests in this case as a carrying capacity for all aspects of human life, animals and plants is largely determined by the low level of human awareness of the importance of forests in the use and management of forests. This research was conducted with the aim of finding out the perceptions of participants in looking at the ecology and economic value produced by forests and as a consideration in determining the pesanggem decisions and to find out the approach to forest area farming to support the welfare of the community. This research was in Blitar, precisely Wonotirto District and Bakung District. Analysis of the data used is descriptive analysis of assessment scores, while to know sugarcane income is to use analysis of income and farm income. The results of the study concluded that the perception of the pesanggem on the ecology and economy of the forest was positive, although there were some pesanggem who had negative perceptions. While the analysis of farm income per ha is Rp. 26,829,023, - with a total cost per Ha of Rp. 10,602,351, - get a profit of $16,226,672$, -, the calculation of R / C Ratio is 2.49 so farming is efficient to run. Production Break Event Point (BEP) is $30,293 \mathrm{Kg}$ and Break Event Point (BEP) price of Rp.139 / Kg, so customers must increase production if they want to get more profits.
\end{abstract}

Keywords: Perception, economy and forest ecology, farming income and income

\section{PENDAHULUAN}

Hutan merupakan paru-paru bumi tempat berbagai satwa hidup, pohon-pohon, hasil tambang dan berbagai sumberdaya lainnya yang bisa didapatkan dari hutan yang tidak ternilai harganya bagi manusia.Hutan juga merupakan sumberdaya alam yang memberikan manfaat besar bagi kesejahteraan manusia, baik manfaat tangible yang dirasakan secara langsung, maupun intangible yang dirasakan secara tidak langsung.Manfaat langsung seperti penyediaan kayu, satwa, obat, dan makanan, sedangkan manfaat tidak langsung seperti manfaat rekreasi, perlindungan terhadap bencana terutama angin dan pengaturan tata air sebagai pencegahan erosi.

Keberadaan hutan dalam hal ini adalah daya dukung hutan terhadap segala aspek kehidupan manusia, satwa dan tumbuhan sangat ditentukan pada tinggi rendahnya kesadaran manusia akan arti penting hutan di dalam pemanfaatan dan pengelolaan hutan. Hutan menjadi media hubungan timbal balik antara manusia dan makhluk hidup lainnya dengan faktor-faktor alam yang terdiri dari proses ekologi dan merupakan suatu kesatuan siklus yang dapat mendukung kehidupan akan tetapi hutan. Mengingat pentingnya arti hutan bagi masyarakat, maka peranan dan fungsi hutan tersebut perlu dikaji lebih lanjut. 
Pemanfaatan sumberdaya alam hutan apabila dilakukan sesuai dengan fungsi yang terkandung di dalamnya, seperti adanya fungsi lindung, fungsi suaka, fungsi produksi, fungsi wisata dengan dukungan kemampuan pengembangan sumberdaya manusia, ilmu pengetahuan dan teknologi, akan sesuai dengan hasil yang ingin dicapai.

Tabel I. Luas Kawasan Hutan Negara di Provinsi Jawa Timur

\begin{tabular}{lrr}
\hline \multicolumn{1}{c}{ Fungsi Hutan } & \multicolumn{1}{c}{ Luas (Ha) } & Persen Luas (\%) \\
\hline Kawasan hutan konservasi (HSA\&HPA) & $230.248,3$ & 16,96 \\
Kawasan hutan lindung (HL) & $315.505,3$ & 23,25 \\
Kawasan hutan produksi : & & \\
A.Kawasan hutan produksi tetap (HP) & $811.452,7$ & 59,79 \\
B.Kawasan hutan produksi terbatas (HPT) & 0 & 0 \\
$\quad$ Total luasan Kawasan Hutan & $1.357 .206,3$ & 100,00 \\
$\quad$ Luas Daratan Provinsi Jawa Timur & $4.792 .300,0$ & 100,00 \\
& & 28,32 \\
Prosentase Luas Kawasan Hutan Provinsi Jawa Timur (\%) & \\
\hline
\end{tabular}

Kabupaten Blitar merupakan salah satu daerah di Propinsi Jawa Timur yang secara geografis terletak pada $11125^{\prime}$ - 112 20' BT dan 7 57-8 9'51 LS berada di barat daya Propinsi Jawa Timur - Surabaya dengan jarak kurang lebih $160 \mathrm{Km}^{2}$. Kabupaten Blitar memiliki luas wilayah $1.588 .79 \mathrm{Km}^{2}$, dengan tata guna tanah terinci sebagai sawah, pekarangan, perkebunan, tambak, tegal dan hutan.Namun demikian seiring dengan perkembangan zaman kawasan hutan di Kabupaten Blitar berangsur-angsur mulai hilang. Hal-hal tersebut berkaitan erat dengan faktor ekonomi masyarakat dikarenakan hutan mempunyai nilai ekonomis untuk kebutuhan masyarakat yang cukup besar seperti halnya perluasan area tanam pada usahatani kawasan hutan yang mungkin saja itu ilegal tanpa sepengetahuan Perum Perhutani, pengambilan kayu, makanan yang bisa diambil di dalam hutan. Selain itu pengalihan fungsi hutan menjadi tempat tinggal, hal tersebut seiring dengan pertambahan jumlah penduduk yang semakin tahun semakin meningkat sehingga memberikan peluang untuk mengubah hutan menjadi tempat tinggal.

Fokus penelitian ini adalah kepada persepsi atau pemahaman pesanggem Kawasan hutan di Kabupaten Blitar tentang nilai ekonomi hutan baik secara tangible (dirasakan langsung) maupun intengibel (dirasakan secara tidak langsung) dan ekologi hutan serta pengelolaan usahatani tanaman tebu di Kawasan hutan yang disertai aturanaturan yang telah tertera pada keputusan perum perhutani yaitu tentang pedoman pengelolaan sumberdaya hutan bersama masyarakat (PHBM).

Fungsi hutan lindung, hutan produksi yang utama adalah sebagai pengatur tata air, paru-paru dunia sampai kegiatan industri.Namun demikian dalam pemanfaatan hutan seringkali masayarakat atau pengelola dalam hal ini adalah petani pesanggem kawasan hutan mangabaikan fungsi hutan yang sebenarnya.

1. Bagaimana persepsi pesanggem dalam memandang ekologi dan nilai ekonomi yang dihasilkan oleh hutan?

2. Bagaimana pendekatan usahatani kawasan hutanguna mendukung kesejahteraan pesanggem?

Berdasarkan perumusan masalah maka tujuan penelitian dapat dirumuskan sebagai berikut: 
1. Untuk mengetahui persepsi pesanggem dalam memandang ekologi dan nilai ekonomi yang dihasilkan oleh hutan serta sebagai pertimbangan dalam menentukan keputusan pesanggem.

2. Untuk mengetahui pendekatan usahatani kawasan hutan guna mendukung kesejahteraan pesanggem.

Berdasarkan penelitian terdahulu yang telah dilakukan dan berdasarkan kerangka pemikiran yang ada, maka dalam penelitian ini dapat dibuat hipotesis:

1. Diduga persepsi pesanggem dalam memandang ekologi dan nilai ekonomi yang dihasilkan oleh hutan bersifat positif.

2. Diduga pendekatanusahatani kawasan hutan efisien untuk diusahakan dan bisa mendukung kesejahteraan petani

\section{METODE PENELITIAN}

\section{Subjek, Objek dan Tempat Penelitian}

Fokus penelitian ini kepada persepsi pesanggem dalam memandang ekologidan nilai ekonomi yang dihasilkan oleh hutanserta pengelolaan usahatani yang diusahakan pada lahan kawasan hutan serta bagaimana pelaksanaan usahataninya. Subjek dari penelitian ini adalah petani penggarap atau pesanggem dilahan kawasan hutan guna mendukung kesejahteraan petani pesanggem.Dalam pelaksanaan penelitian di lapang, pesanggem dijadikan sebagai responden yang mengelola lahan kawasan hutan.

Tempat penelitian dilakukan pada Kecamatan Bakung, Kecamatan Wonototirto Kabupaten Blitar.Daerah ini terletak di kawasan Blitar selatan berdekatan dengan wilayah pantai selatan. Dasar penentuan daerah ini adalah karena Kecamatan Bakung dan Kecamatan Wonotirto daerah yang letaknya persis di kawasan hutan.

\section{Jenis Penelitian dan Penarikan Sampel}

Penelitian ini menggunakan analisisi deskriptif untuk mengetahui persepsi petani penggarap kawasan hutan dalam pengelolaan usahataninya di wilayah Kabupaten Blitar.Analisis dilakukan dengan tabel distribusi frekuensi digunakan untuk mengitung besarnya frekuensi data dari masing-masing katagori data.Sedangkan nilai rata-rata digunakan sebagai dasar untuk menguji beda persepsi antar petani penggarap. Sumber data dan caramenentukannya, Jenis data yang dikumpulkan dalam penelitian ini meliputi data primer dan data sekunder.Penarikan sampel merupakan langkah untuk memperoleh respondenyaitu orang- orang yang diwawancarai berdasarkan kriteria yang telah ditetapkan.Dalam penelitian ini responden adalah petani penggarap atau pesanggemdi kawasan hutan.Penentuan responden dengan menggunakan Metode Acak Sederhana (Simple Random Sampling).Proses pengambilan sampel dilakukan dengan memberi kesempatan yang sama pada setiap anggota populasi untuk menjadi anggota sampel. Proses memilih sejumlah sampel dari populasi $\mathrm{N}$ dilakukan secara randomatau secara acak.Jumlah sampel yang diambil sebayak 80pesanggem sebagai responden yang tersebar di Wilayah Kecamatan Bakung, Kecamatan Wonotirto Kabupaten Blitar.

\section{Rancangan Uji Hipotesis}

Data yang dihasilkan dari penelitian ini adalah data atas jawaban pertanyaan indikator variabel.Terdapat dua puluh variabel yang digunakan sebagai indikator untuk mengetahui persepsi pesanggem berupa pertanyaan-pertanyaan yang disampaikan kepada responden dengan menggunakan kuisioner. 
Kuisioner disusun menggunakan metode likert dimana responden diminta untuk menyatakan persetujuan atau ketidak setujuan terhadap isi pernyataan dalam lima kategori jawaban mulai dari " sangat tidak setuju (STS), "Tidak Setuju (TS), " RaguRagu (R), 'Setuju"' (S), " Sangat Setuju'(SS). Data yang diperoleh dari kuisioner adalah data ordinal, untuk bisa diolah menggunakan analisis statistik parametrik maka data tersebut harus ditransformasi menjadi data interval.Alat yang digunakan untuk transformasi data ordinal ke interval adalah menggunakan Method of Succesive Interval (MSI). Pentransformasian dilakukan terhadap masing-masing item pertanyaan, sehingga hasil akhir skala interval dari masing-masing item pertanyaan akan berbeda meskipun pilihan jawaban responden sama.

Langkah-langkah untuk merubah data dari data ordinal ke data interval menggunakan MSI adalah sebagai berikut:

1. Mengubah nilai jawaban responden ke dalam angka dengan ketentuan, dimana untuk peryataan item positif jawabanya Sangat Tidak Setuju (STS) diberi nilai 1, Tidak Setuju (TS) diberi nilai 2, Ragu-ragu (R) diberi nilai 3, Setuju (S) diberi nilai 4, Sangat Setuju (SS) diberi nilai 5. Untuk pertanyaan negatif diberi nilai sebaliknya yaitu 5, 4, 3, 2, 1 .

2. Menghitung frekuensi masing-masing skor jawaban dalam skala ordinal.

3. Menghitung proporsi untuk setiap frekuensi skor

4. Menjumlahkan proporsi secara berurutan untuk setiap respon, sehingga diperoleh nilai proporsi kumulaitf

5. Menentukan nilai $\mathrm{z}$ untuk setiap kategori, dengan asumsi bahwa proporsi kumulatif dianggap mengikuti distribusi normal baku. Nilai $\mathrm{Z}$ diperoleh dari tabel distribusi normal baku.

6. Menghitung nilai densitas dari nilai $\mathrm{Z}$ yang diperoleh dengan cara memasukkan nilai $Z$ tersebut ke dalam fungsi densitas normal baku.

7. Menghitung SV (Scale Value).

8. Mengubah Scale Value (SV) terkecil (nilai negative yang terbesar) menjadi sama dengan satu (1), jika kategori satu (1) terdapat frekuensinya dan nilai selanjutnya ditambahkan selisih dari (1) dikurangi Scale Valu (SV).

9. Mentransformasikan nilai skala ke masing-masing skala ordinal dalam satu item pernyataan.

Data yang telah dikonversi menjadi data interval selanjutnya dijumlahkan dan hasilnya diinterpretasikan terhadap ketentuan sebagai berikut:

- Nilai Tertinggi = total responden $\mathrm{x}$ bobot tertinggi $\mathrm{x}$ jumlah penyataan

$$
=80 \times 5 \times 22=8.800
$$

- Nilai Terendah $=$ total responden $\mathrm{x}$ bobot terendah $\mathrm{x}$ jumlah

$$
\text { pernyataan }
$$

$$
=80 \times 1 \times 22=1760
$$

- Rentang Skala $=\frac{\text { nilai tertinggi }- \text { nilai terenda } h}{\text { jumla } h \text { kelas }}$

$$
=\frac{8.800-1760}{2}=3520
$$

Hipotesis :

Ho $=$ Persepsi petani penggarap dalam memandang ekologi hutan dan nilai ekonomi yang dihasilkan oleh hutan bersifat negatif.

$\mathrm{H} 1=$ Persepsi petani penggarap dalam memandang ekologi hutan dan nilai ekonomi yang dihasilkan oleh hutan bersifat positif.

Interpretasi hasil perhitungan: 


$$
\begin{aligned}
& 1760-5280=\text { Persepsi negatif }(\mathrm{H} 0 \text { diterima dan Ha ditolak) } \\
& 5280-8800=\text { Persepsi positif ( H0 ditolak dan Ha diterima) }
\end{aligned}
$$

Analisis Pendapatan dan Penerimaan Usahatani

Pendapatan usahatani merupakan selisih antara total penerimaan dan total semua biaya yang dikeluarkan. Penerimaan adalah semua hasil produksi yang diperoleh dikalikan dengan harga jual, penerimaan usahatani secara matematis dirumuskan sebagai berikut:

$$
\begin{aligned}
& \text { TR = P } . \mathrm{Q} \\
& \text { Dimana : } \\
& \text { TR = Total Revenue (Penerimaan Total) } \\
& \mathrm{P}=\text { Harga Output (Harga Produksi) } \\
& \mathrm{Q}=\text { Output (Produksi) }
\end{aligned}
$$

Pendapatan usahatani secara matematis dirumuskan sebagai berikut:

$$
\pi=\mathrm{TR}-\mathrm{TC}
$$

Dimana :

$$
\begin{aligned}
& \pi=\text { Profit } \\
& \text { TR }=\text { Total Revenue }(\text { Penerimaan Total }) \\
& \text { TC }=\text { Total Cost }(\text { Biaya Total })
\end{aligned}
$$

\section{Break Event Point (BEP)}

Break Event Point merupakan analisis yang digunakan untuk mengetahui besarnya pendapatan pada saat titik balik modal, atau dengan kata lain pendapatan tidak mengalami keuntungan juga tidak mengalami kerugian(titik impas). Analisis $B E P$ ada 2 macam.Secara sistematis dapat dihitung dengan cara sebagai berikut :

$$
B E P \text { atas dasar produksi : }
$$

Dimana: $\mathrm{TC}=$ Total Cost

$$
B E P(\text { Produksi })=\frac{T C}{P}
$$

$$
\mathrm{P}=\text { Harga Jual }
$$

Sedangkan untuk mengetahui $B E P$ atas dasar harga secara sistematis dapat dihitung dengan cara sebagai berikut :

$B E P$ atas dasar harga :

Dimana:TC $=$ Total Cost

$$
B E P(\text { Harga })=\frac{T C}{Q}
$$

$$
\mathrm{Q}=\text { Jumlah Produksi }
$$

- $\quad R / C$ (Return Cost Ratio)

$R / C$ (Return Cost Ratio) merupakan perbandingan atau nisbah antara penerimaan dan biaya. Secara matematik dapat ditulis sebagai berikut :

$$
\mathrm{R} / \mathrm{C} \text { Ratio }=\frac{T R}{T C}
$$

Dimana $: T R=$ Total Revenue (Penerimaan Total)

$\mathrm{TC}=$ Total Cost (Biaya Total)

Kriteria :Jika R/C >1, maka usaha layak untuk dilaksanakan 
Jika $\mathrm{R} / \mathrm{C}=1$, maka usaha layak impas

Jika $\mathrm{R} / \mathrm{C}<1$, maka usaha tidak layak

\section{HASIL PENELITIAN DAN PEMBAHASAN}

Berdasarkan kuisioner yang telah diisi oleh responden dilakukan pemilahan jawaban sesuai dengan masing-masing pertanyaan.Hasil rekapitulasi jawaban responden dapat dilihat pada lampiran 2.Selanjutnya dari data yang sudah direkap tersebut, masingmasing diberikan nilai dimana untuk pertanyaan item positifjawaban jawaban sangat tidak setuju ( STS) diberi nilai 1, tidak setuju (TS) diberi nilai 2, ragu-ragu (R) diberi nilai 3, setuju (S) diberi nilai 4 dan sangat setuju (SS) diberi nilai 5.Sedangkan untuk pertanyaan negatif diberi nilai sebaliknya yaitu (STS) diberi nilai 5, tidak setuju (TS) diberi nilai 4, ragu-ragu (R) diberi nilai 3, setuju (S) diberi nilai 2 dan sangat setuju (SS) diberi nilai 1. Hasil pemberian nilai dari jawaban responden ini dapat dilihat pada lampiran 3.

Karena nilai tersebut merupakan data ordinal maka untuk keperluan statistikparametric, data tersebut harus diubah kedalam data interval dengan menggunakan Method of Succesive Interval (MSI).Pengolahan data menggunakan program MSI dapat dilihat pada lampiran 4.Setelah diketahui data interval selanjutnya dilakukkan pengkonversian data ordinal ke interval sesuai dengan skor masing-masing.

Tabel Rekapitulasi Hasil Analisa Data Persepsi Pesanggem Terhadap AspekEkonomi dan Ekologi Hutan

\begin{tabular}{cccc}
\hline Jumlah Responden & $\begin{array}{c}\text { Jumlah Skor Data } \\
\text { Interval }\end{array}$ & Rata-rata & Standart Deviasi \\
\hline 80 & 6720,36 & 84,04 & 3,61 \\
\hline
\end{tabular}

Sumber Data: Data peneliti diolah 2015

Dari interpretasi hasil perhitungan jumlah skor data interval dari persepsi pesanggem terhadap aspek ekonomi dan ekologi hutan, apabila jumlahnya diantara 1760 - 5280 termasuk kategori persepsi negative dan apabila jumlahnya 5280 - 8800 maka termasuk dalam katagori positif. Berdasarkan tabel 4.3.diatas diketahui bahwa nilai keseluruhan persepsi pesanggem terhadap aspek ekonomi dan ekologi hutan berjumlah 6720,36 sehingga dapat disimpulkan bahwa persepsi pesanggem terhadap aspek ekonomi dan ekologi hutan secara keseluruhan adalah bersifat positif. Dengan demikian hipotesis yang diajukan dalam penelitian ini dapat diterima.Dibandingkan dengan nilai maksimal yang mencapai 8.800, nilai 6720 apabila diprosentase mencapai 76,36\% dari nilai persepsi maksimal. Artinya bahwa masih cukup banyak responden yang memberikan persepsi negatif terhadap nilai ekonomi dan ekologi hutan.

Untuk mengetahui kekurangan dan kelebihan dalam pengelolaan sumber daya hutan yang dianggap oleh responden atau pesanggem, dilakukan pengelompokan tingkat persepsi pesanggem terhadap nilai ekonomi dan ekologi hutan. Katagori persepsi masingmasing pesanggem dibagi dalam 3 (tiga) katagori:

- Negatif, jika jumlah skor individu dibawah dari nilai rata-rata kelompok dikurangi standart deviasi.

- Cukup positif, jika jumlah skor individu berada diantara nilai katagori negatif dan positif. 
- Sangat Positif, jika jumlah skor individu diatas dari nilai rata-rata kelompok dan ditambah dengan standart deviasi.

Dengan rata-rata sebesar 84,04 dan standart deviasi 3,61 maka penentuan katagori persepsi untuk masing-masing responden adalah:

- Negatif jika jumlah skor responden kurang dari 80,43

- Cukup positif jika jumlah skor responden diantara 80,43 - 87,65

- Sangat positif jika jumlah skor responden lebih dari 87,65

Tabel Rekapitulasi Katagori Persepsi Pesanggem Terhadap Aspek Ekkonomi dan Ekologi Hutan Secara Individual.

\begin{tabular}{clcc}
\hline No & \multicolumn{1}{c}{ Katagori } & Jumlah Responden & Prosentase \\
\hline 1 & Negatif & 12 & $15 \%$ \\
2 & Cukup positif & 10 & $12,5 \%$ \\
3 & Sangat positif & 58 & $72,5 \%$ \\
\hline \multicolumn{2}{l}{ Jumlah } & 80 & $100 \%$ \\
\hline
\end{tabular}

Sumber Data: Data peneliti diolah 2015

Berdasarkan tabel diatas, diketahui bahwa sebagian besar responden masuk dalam katagori cukup positif, hanya beberapa pesanggem yang dalam katagori sangat positif.Hal ini menunjukkan bahwa ada beberapa pernyataan mengenai nilai ekonomi dan ekologi hutan yang belum memuaskan bagi sebagian responden sehingga persepsi rendah atau cenderung negatif.

Dari semua jawaban responden terhadap pertanyaan tentang hutan yang diajukan cenderung menyebar dari sangat tidak setuju sampai sangat setuju.Hal ini menunjukkan bahwa ada responden yang merasa puas maupun merasa tidak puas.Item pernyataan yang mendapatkan penilaian rendah diantaranya bahwa responden menilai hutan cenderung kurang memenuhi kebutuhan sehari-hari. Sehingga mayoritas pesanggem lebih menfokuskan usahataninya ketimbang memanfaatkan hasil hutan yang tidak menentu untuk kebutuhan sehari-hari.

Selain itu mayoritas pesanggem telah melanggar aturan yang diberikan oleh lembaga terkait tentang pengelolaan hutan bersama masyarakat, mereka seharusnya memanfaatkan sumber daya hutan dengan baik dan benar namun karena tuntutan ekonomi yang tidak sesuai dengan pendapatan yang dihasilkan dari hutan, maka pesanggem mengusahatanikan pertanianya dengan menanami komoditas tebu dimana komoditas tersebut sebenarnya tidak boleh untuk ditaman pada lahan hutan lindung, hutan konservasi dan hutan produksi karena dapat merusak tanaman pokok dan merusak kelestarian hutan.

Apabila dikaitkan dengan tingkat pendidikan, rata-rata pendidikan responden antara SD sampai S1, namun pesanggem yang berpendidikan tinggi hanyalah sebagian kecil dari pesanggem keseluruhan.Hasil persepsi pesanggem terhadap ekonomi dan ekologi hutan secara individual merata pada semua kategori.Ada pesanggem dengan tingkat pendidikan SD memberikan persepsi negative namun juga memberikan persepsi positif, demikian juga pesanggem yang berpendidikan SMP sampai S1, mereka juga memberikan persepsi yang merata pada setiap katagori. Hal ini dapat disimpulkan bahwa tingkat pendidikan pesanggem tidak terlalu berpengaruh secara signifikan pada persepsi pesanggem terhadap ekonomi dan ekologi hutan. Tingkat pendidikan biasanya berpengaruh cukup besar terhadap hal-hal yang berkaitan seseorang untuk menganalisis suatu permasalahan, artinya pengelolaan sumber daya hutan secara tidak benar dan tepat 
akan menimbulkan kelestarian hutan itu sendiri, sehingga hal-hal semacam itu perlu adanya analisis tertentu.

\section{Hasil Analisis Usahatani Tebu}

Luas lahan yang dikelola oleh pesanggem cukup beragam mulai dari yang terendah 0,25 ha sampai yang tertinggi 2 ha, mayoritas penguasaan lahan pesanggem diatas 0,5 ha, karena semakin luas penguasaan maka pendapatan yang diperoleh juga semakin besar.

Tabel. Luas Lahan Pesanggem

\begin{tabular}{cccc}
\hline No & $\begin{array}{c}\text { Luas Lahan } \\
\text { (Hektar) }\end{array}$ & $\begin{array}{c}\text { Jumlah } \\
\text { Pesanggem }\end{array}$ & $\begin{array}{c}\text { Prosentase } \\
(\%)\end{array}$ \\
\hline 1. & $0-0,5$ & 34 & 42,50 \\
2. & $0,6-1$ & 29 & 36,25 \\
3. & $1-2$ & 17 & 21,25 \\
\hline
\end{tabular}

Sumber Data: Data peneliti diolah 2015

Berdasarkan diatas pesanggem yang menguasai luas lahan 0-0.5 ha adalah 34 jumlah tersebut adalah jumlah yang tertinggi karena jumlah penduduk untuk Kecamatan Bakung dan Kecamatan Wonotirto sekarang sudah cukup banyak sehingga penguasaan lahan dibagi oleh beberapa orang pesanggem, sedangkan untuk penguasaan 0,6-2 ha, penguasaaan tersebut cukup banyak karena mereka sudah lebih dulu mengelola lahan hutan sebelum masyarakat menetap di kecamatan Bakung dan Kecamatan Wonotirto.

- Biaya Variabel

Setiap petani pasti menginginkan keuntungan yang tinggi dari kegiatan mengolah komoditi yang mereka tanam. Selain teknik budidaya yang harus diperhatikan, biaya produksi merupakan komponen penting yang juga perlu diperhatikan agar usahatani tebu bisa efisien. Biaya yang dikeluarkan dalam budidaya tebu diasumsikan biaya perusahaan, biaya dalam usahatani tebu meliputi biaya variabel dan biaya tetap.Biaya variabel adalah biaya yang dikelurkan oleh besarnya produksi, biaya variabel meliputi biaya sarana produksi dan tenaga kerja. Biaya tetap adalah biaya yang besar kecilnya tidak dipengaruhi oleh produksi, biaya tetap dalam usahatani tebu adalah sewa lahan dan penyusutan alat berupa traktor, cangkul dan sabit. Berikut ini adalah tabel 4.6 biaya yang dikeluarkan untuk memenuhi kebutuhan sarana produksi 
Eko Wahyu Budiman 2019. Persepsi Pesanggem Terhadap Aspek Ekonomi Dan Ekologi Hutan Di Kabupaten Blitar. Journal Viabel Pertanian. (2019), 13(1)21-32

Tabel.Rata-rata Penggunaan Biaya Variabel (Variabel Cost) Per Hektar

\begin{tabular}{|c|c|c|c|}
\hline No & Uraian & Jumlah & Total (Rp) \\
\hline \multirow[t]{4}{*}{1} & Pupuk & & \\
\hline & - Organik & $166,25(\mathrm{Kg})$ & 83.125 \\
\hline & $-\quad \mathrm{ZA}$ & $363,75(\mathrm{Kg})$ & 509.250 \\
\hline & - NPK & $428,50(\mathrm{Kg})$ & 1.109 .750 \\
\hline \multirow[t]{3}{*}{2} & Herbisida & & \\
\hline & - Amexson & 0,96 (Liter) & 88.550 \\
\hline & - $\quad$ Starmind & 0,5 (Liter) & 36.000 \\
\hline \multirow[t]{7}{*}{3} & Tenaga Kerja & & \\
\hline & - Mengolah Tanah & 43 (Hari) & 2.155 .625 \\
\hline & - menanam & 24 (Hari) & 1.171 .875 \\
\hline & - Menyiang & 10 (Hari) & 503.750 \\
\hline & - Menyemprot & 0,7 (Hari) & 106.875 \\
\hline & - Memupuk & 9,8 (Hari) & 502.500 \\
\hline & Total Biaya Variabel & & 5.656 .675 \\
\hline
\end{tabular}

Sumber Data: Data peneliti diolah 2015

Berdasarkan tabel diatas total biaya variabel sebersar Rp.5.656.675,00 dari beberapa pengeluaran tersebut biaya yang paling besar adalah tenaga kerja terutama pada pengolahan tanah, karena dalam budidaya tebu langkah awal yang dilakukan sebelum menanam adalah membuat puritan, kegiatan tersebut membutuhkan waktu yang cukup lama dikarenakan dalam pengerjaanya sebelum musim hujan sehingga tanah yang dicangkul tersebut cukup sulit, sedangkan untuk penggunaan pupuk, pupuk yang digunakan cukup banyak karena tanaman tebu membutuhkan pupuk yang lebih supaya tanaman tebu tersebut bisa berbobot, dalam arti semakin banyak penggunaan pupuk maka berat tebu akan semakin bertambah, selain itu semakin banyak penggunaan pupuk ZA maka kadar gula pun semakin tinggi, sehingga bisa meningkatkan nilai jual. Sedangkan untuk penggunaan herbisida tidak terlalu banyak karena rumput yang setelah disemprot dengan herbisida biasanya tidak akan tumbuh lagi, Sehingga penggunaan herbisida lebih efesien dari pada menggunakan tenaga kerja yang membersihkan rumput.

- Biaya Tetap (Fix Cost)

Biaya tetap merupakan biaya yang dikeluarkan untuk proses produksi, dimana dalam penggunaanya tidak habis dalam satu kali proses produksi atau dalam kata lain biaya yang besar kecilnya tidak dipengaruhi oleh produksi. Biaya tetap meliputi alat dan lahan, dalam perhitungan penggunaan alat tersebut ada nilai penyusutan yang mana ratarata penyusutannya adalah 5 tahun. Untuk mengetahui seberapa besar biaya yang dikeluarkan dalam investasi dapat dilihat pada tabel 4.7.dibawah ini.

Tabel. Rata-rata Penggunaan Biaya Tetap (Fix Cost) Per Hektar

\begin{tabular}{|c|c|c|c|}
\hline No & Uraian & Jumlah & Total (Rp) \\
\hline 1 & Sewa Lahan & $1(\mathrm{Ha})$ & 2.000 .000 \\
\hline 2 & Bibit & $4.938(\mathrm{Kg})$ & 1.975 .000 \\
\hline 3 & Alat & & \\
\hline & Sabit & 2 (Unit) & 15.000 \\
\hline & - Cangkul & 0,6 (Unit) & 42.000 \\
\hline \multirow{2}{*}{\multicolumn{2}{|c|}{$\begin{array}{l}-\quad \text { Sprayer } \\
\text { Jumlah }\end{array}$}} & 1,9 (Unit) & 56.625 \\
\hline & & & 4.088 .625 \\
\hline
\end{tabular}

Sumber Data: Data peneliti diolah 2015 
Berdasarkan tabel diatas Biaya yang dikeluarkan dalam penyewaan lahan adalah sebesar Rp.2.000.000/ 1 Ha dalam satu tahun, karena dalam perhitungan usahatani, lahan harus dihitung sewa. Sedangkan untuk jumlah benih $4.938 \mathrm{Kg}$ dengan luas lahan $1 \mathrm{Ha}$ dengan total biaya sebesar Rp.1.975.000,00. Jumlah bibit tersebut adalah yang paling besar karena semakin dekat jarak tanam tebu maka produksinya pun juga akan semakin banyak. Untuk biaya alat seperti sabit,cangkul dan spreyer tidak terlalu besar karena setiap pesanggem hanya memiliki 1 sampai 2 unit alat, sehingga biayanya pun relatif kecil. Dari masing-masing alat tersebut nilai penyusutanya meliputi sabit Rp.15.000,00 cangkul Rp.42.000,00 dan spreyer Rp.56.625,00 perhitungan penyusutan tersebut selama 5 tahun.

- Rata-Rata Produksi, Penerimaan, Pendapatan, dan R/C Ratio Tanaman Tebu

Jumlah produksi tebu biasanya selalu meningkat maupun menurun pada tahuntahun berikutnya, hal itu tergantung pada pola perawatan termasuk pemupukan yang tepat waktu maupun sesuai dengan anjuran penggunaan, selain itu cuaca juga sangat berpengaruh terhadap jumlah produksi tanaman tebu, semakin tinggi intensitas hujan maka produksi tebu juga akan semakin meningkat. Untuk mengetahui jumlah produksi, penerimaan, pendapatan dan R/C Ratio dapat dilihat pada tabel dibawah ini:

Tabel. Jumlah Produksi, Penerimaan, Pendapatan dan R/C Ratio Per Hektar

\begin{tabular}{clcc}
\hline No & \multicolumn{1}{c}{ Uraian } & Jumlah & Nilai \\
\hline 1 & Produksi Tebu & $76.654 \mathrm{Kg}$ & 26.829 .023 \\
2 & Total Biaya (TC) & & 10.602 .351 \\
3 & Pendapatan & 16.226 .672 \\
4 & R/C Ratio & & 2,49 \\
\hline
\end{tabular}

Sumber Data: Data peneliti diolah 2015

Berdasarkan tabel diatas produksi tebu sebesar $76.654 \mathrm{Kg}$ dengan jumlah nilai uang sebesar Rp.26.829.023,00 dan harga per kg nya adalah Rp.350. Jumlah produksi tersebut sudah termasuk dalam katagori tanaman tebu bagus karena mengingat lokasi lahan berada pada dataran tinggi dan tanah untuk wilayah Kabupaten Blitar selatan termasuk tanah yang kering atau tanah gembur, sehingga tanaman tebu apabila lama tidak terkena air maka akan cepat kering. Total biaya yang dikeluarkan dalam satu kali musim adalah sebesar Rp.10.602.351,00. Nilai tersebut cukup besar karena tenaga kerja dalam mengolah tanah membutuhkan waktu yang relatif lama karena faktor tanah yang sulit untuk dicangkul.Pendapatan usahatani tebu dalam 1 Ha rata-ratanya adalah Rp.16.226.672,00, pendapatan tersebut apabila dibandingkan dengan tanaman polowijo seperti tanaman jagung, kacang tanah itu lebih besar, serta tanaman tebu tidak terlalu membutuhkan perawatan yang lebih dari pada tanaman yang lainnya.

R/C Ratio adalah perhitungan yang menunjukan suatu usahatani efisien untuk diusahakan atau tidak, cara menghitung $\mathrm{R} / \mathrm{C}$ Ratio yaitu total penerimaan dibagi dengan total biaya. Ketentuan R/C Ratio yaitu, jika R/C > 1, maka usahatani efisien untuk diusahakan, $\mathrm{R} / \mathrm{C}=1$ maka usahatani pada titik impas (tidak mengalami rugi juga tidak untung), $\mathrm{R} / \mathrm{C}<1$ maka usahatani mengalami rugi atau tidak efisien.

\section{- Break Event Point Harga dan Break Event Point Produksi}

Break Event Point merupakan salah satu analisis yang digunakan untuk mengetahui besarnya pendapatan pada saat titik balik modal (Titik impas), sehingga tidak mengalami kerugian dan keuntungan dalam usahatani tanaman tebu, petani bisa mengetahui harga rata-rata penjualan serta produksi usahatani tidak rugi atau untung. Break Event Point untuk usahatani tebubisa dilihat pada tabel 4.9 berikut ini: 
Eko Wahyu Budiman 2019. Persepsi Pesanggem Terhadap Aspek Ekonomi Dan Ekologi Hutan Di Kabupaten Blitar. Journal Viabel Pertanian. (2019), 13(1)21-32

Tabel . Break Event Point Harga dan Break Event Point Produksi

\begin{tabular}{clc}
\hline No & \multicolumn{1}{c}{ Uraian } & \multicolumn{1}{c}{ Jumlah } \\
\hline 1 & Biaya Produksi per ha & Rp.10.602.351 \\
2 & Harga jual rata-rata & Rp.350/Kg \\
3 & Jumlah produksi & $76.654 \mathrm{Kg}$ \\
4 & BEP (Produksi) & $30.293 \mathrm{Kg}$ \\
5 & BEP (harga) & $\mathrm{Rp} .139 / \mathrm{Kg}$ \\
\hline
\end{tabular}

Sumber Data: Data peneliti diolah 2015

Berdasarkan tabel diatas menunjukkan hasil perhitungan titik impas harga dan titik impas produksi.Titik impas harga tanaman tebu adalah sebesar Rp.139/Kg, harga tersebut diperoleh dari perhitungan total biaya (total cost) dibagi dengan jumlah produksi. Harga rata-rata tersebut sebagai acuan penjualan tebu agar tidak mengalami kerugian, sedangkan untuk titik impas produksi sebesar $30.293 \mathrm{~kg} / \mathrm{ha}$ dengan perhitungan total biaya dibagi dengan harga rata-rata, jumlah produksi tersebut dapat mengembalikan biaya yang dikeluarkan oleh pesanggem namun tidak memberikan sebuah keuntungan, supaya mendapatkan keuntungan pesanggem harus berusa menambah produksinya. Semakin besar produksi pesanggem maka semakin besar keuntungan yang diperoleh.

\section{KESIMPULAN DAN SARAN}

\section{Kesimpulan}

Berdasarkan hasil penelitian dan pembahasan yang telah diuraikan pada bab sebelumnya, maka dalam penelitian tesis ini dapat ditarik kesimpulan sebagai berikut:

1. Secara keseluruhan persepsi pesanggem terhadap aspek ekonomi dan ekologi hutan di Kabupaten Blitar adalah positif meskipun ada beberapa pesanggem yang mempunyai persepsi negatif.

2. Secara umum pemanfaatan hutan sangat membantu pesanggem dalam memenuhi kebutuhan sehari-hari, namun sebagian dari pesanggem merasa kurang mengenai pemanfaatan hutan sehingga pesanggem tersebut mempunyai persepsi yang negatif.

3. Berdasarkan analisis usahatani budidaya tebu, rata-rata pesanggem mengeluarkan biaya sebesar Rp. 10.602.351,-/ha, dengan penerimaan sebasar Rp. 26.829.023,/ha dengan dikurangi total biaya maka keuntungan bersih sebesar Rp.16.226.672,-/ha.

4. Nilai R/C Ratio budidaya tebu adalah 2,49 yang artinya efisien untuk diusahakan, karena mempunyai keuntungan $149 \%$.

5. Break even point adalah titik impas usahatani tidak mengalami kerugian maupun keuntungan, BEP produksi budidaya tebu sebesar $30.293 \mathrm{Kg} / \mathrm{ha}$ sedangan pada BEP harga sebesar Rp.139/kg, Sehingga pesanggem harus menambahkan produksinya jika ingin memperoleh keuntungan yang lebih besar.

Saran

1. Bagi Perum Perhutani selaku pengendali dan pengawas dalam kagiatan pengelolaan hutan yang dilakukan oleh pesanggem, maka diharapkan terus melakukan pembimbingan kepada pesanggem supaya dalam mengelola sumberdaya hutan tidak sampai merusak atau melakukan hal-hal yang sudah ditetapkan oleh pihak Perum Perhutani.

2. Bagi Pesanggem, dalam mengelola atau memanfaatkan sumberdaya hutan untuk selalu menaati aturan yang telah ditetapkan oleh pihak Perhutani, sedangkan 
dalam usahatani budidaya tebu diharapkan pesanggem lebih meningkatkan pemeliharaanya supaya produksi tebu meningkat dan memperoleh keuntungan yang besar.

\section{DAFTAR PUSTAKA}

Arikunto, S. 2002. Prosedur Suatu Penelitan: Pendekatan Praktek. Edisi Revisi Kelima. Penerbit Rineka Cipta. Jakarta.

Badan Penelitian Dan Pengembangan Pertanian.2007,Prospek Dan Arah Pengembangan Agribisnis Tebu. Edisi kedua. Departemen pertanian

Badan Pusat Statistik.2014, Profil Kecamatan Bakung dan Kecamatan Wonotirto

Bimo Walgito (1990). Pengantar Psikologi Umum, yogyakarta :Andi

Keputusan Menteri Kehutanan No. 417/Kpts-II/1999 tentang Penunjukan KawasanHutan dan Perairan Provinsi Jawa Timur

Luas Kawasan Hutan Negara Provinsi Jawa TimurBerdasarkan SK MENHUT No. 417/Kpts-II/1999

Miftah Thoha. 2003, Kepemimpinan Dalam Manajemen Jakarta : PT. Raja Grafindo Persada.

Peraturan Menteri Kehutanan Nomor : P.33/Menhut-II/2007 Tentang Perubahan Kedua Atas Peraturan Menteri Kehutanan Nomor p.51/Menhut-li/2006

Porwono. 2011, Efisiensi Penggunaan Air Pada Budidaya Tebu di Lahan Kering, Pascasarjana, Institut Pertanian Bogor

Reksohadiprodjo. S. dan Brodjonegoro. B.P, 2000. Ekonomi Lingkungan (Suatu Pengantar). BPFE. Yogyakarta

Soerianegara, I. 1996. Beberapa Pemikiran tentang Pengelolaan Hutan Lindung.Gagasan, Pemikiran dan Karya Prof. Dr. Ir. H. Ishemat Soerianegara, MSc.Disunting oleh E. Suhendang, C. Kusuma, Istomo dan L.Syaufina. InstitutPertanian Bogor. Bogor.

Soekartawi, 1995. Analisis Usahatani. Penerbit Universitas Indonesia (UI Press). Jakarta

Soerianegara, I dan Indrawan A. 1998. Ekologi Hutan Indonesia. Institut PertanianBogor. Bogor.

Sugihartono, dkk. 2007. Psikologi Pendidikan. Yogyakarta: UNY Press.

Sunaryo. 2004. Psikologi Untuk Keperawatan. Jakarta:EGC.

Usman, Husaini. 2006. Pengantar Statistik. Jakarta:PT Bumi Aksara.

Walgito, Bimo, 2004. Pengantar Psikologi Umum, Yogyakarta

Waidi. (2006). The Art of Re-engineering Your Mind for Success. Jakarta: Gramedia.

Widayanti, 2008. Analisis Pendapatan Usahatani Dan Pemasaran Ubi Jalar. Skripsi. Jurusan Ekonomi Pertanian Dan Sumberdaya. Institut Pertanian Bogor. 